\title{
The Meaning Of Policy Guarantee To Protect The Insured In Insurance
}

\author{
$1^{\text {st }}$ Feibe Engeline Pijoh \\ Legal Studies Program \\ Social Scienc Faculty Universitas \\ Negeri Manado \\ Manado, Sulawesi Utara \\ feibepijoh@yahoo.com
}

\author{
$2^{\text {nd }}$ Isye Junita Melo \\ Study Program Law Science \\ Faculty of Social Science \\ Universitas Negeri Manado \\ Manado, Indonesia \\ isyemelo@unima.ac.id
}

\author{
$4^{\text {th }}$ Budi Hermono \\ Law Departement \\ Faculty of Social Sciences and Law \\ Universitas Negeri Surabaya \\ Surabaya, Indonesia \\ budihermono@unesa.ac.id
}

\author{
$3^{\text {rd }}$ Wellem R. Mawitjere \\ Law Science Study Program \\ Faculty of Social Science \\ Universitas Negeri Manado \\ Manado, Indonesia \\ wellemmawitjere@unima.ac.id
}

\begin{abstract}
The purpose of this study is to examine and analyze what the policy guarantee means to protect the insured in insurance, by referring to Article 53 of Law No. 40 of 2014 concerning Insurance. This research is a legal research, especially research on the Law of the Republic of Indonesia, No. 402014 concerning Insurance. This legal research is conducted to produce a new concept as a perspective in solving the problems faced, so that the results obtained in this study will provide a value. This study uses a philosophical approach, which examines insurance issues which include the nature, value and meaning of policy guarantees, as well as a conceptual approach that examines concepts related to the meaning of insurance policies in insurance, then analyzed qualitatively by providing in-depth and thorough explanations and evaluating primary legal material used as a description of the meaning of policy guarantees for the insured person. The meaning of this policy guarantee is reviewed using the theory of legal protection, to get a concept of fair protection for the insured, as well as guaranteeing the rights of the insured against insurance problems that occur and the guarantee of legal certainty for the insured will be achieved.
\end{abstract}

Keywords-Policy guarantees, insured, insurance.

\section{INTRODUCTION}

Society really needs the existence of insurance services as one of the financial means in dealing with the most basic risks that can occur in human life, whether it is a natural risk such as the risk of death associated with a person's soul, or the risk of losing his property because of various things beyond human desire such as natural disasters, accidents, and others.

Awareness of the importance of insurance is not high for the people of Indonesia. The level of awareness of community insurance is still relatively low compared to the awareness of tolerance in other countries. The assessment is especially seen from the point of view of the industry penetration rate for the national market of individual customers, which is only about five million of the 220 million people of Indonesia who are currently listed as insurance policy holders individually, and even then there are some people who have more than one policy [1].

Many factors causing the condition of insurance awareness are still very low. The level of community welfare, measured by per capita income which is still very low, that may be said to be the main cause. Coupled with the world capacity of insurance business which is still relatively low so that efforts to educate the public are still limited. This education is very important to increase awareness, at least people's understanding of the importance of insurance. In addition, the reality that occurs in the community often discourages insurance, because the difficulties that occur in the process of filing claims are often experienced by the insured. This is not balanced with the obligation of the insured who has made premium payments. This condition often creates a bad image for the insurance industry.

Humans should be more aware that insurance has a very important and useful role in human life, such as [2]:

1. Providing a sense of security or a sense of security in running a business from an uncertain to certain. This is because a person will be free from worry about being hit by a loss due to an unexpected event, because even if the loss is suffered, he will get compensation from the insurance company;

2. Increase the efficiency and activities of the company, because by shifting the greater risk to the insurance company, the company will pay attention to increasing its business;

3. It tends to lead to an estimate of a reasonable cost assessment, with the anticipation of a risk that can be estimated in advance, the company is allowed to calculate the premium expenditure, but will get compensation from insurance, as a cost that must be incurred by the company;

4. It is the basis for consideration of a loan application to a bank, in the event that the company borrows credit from the bank, the bank usually asks the debtor to cover insurance for collateral; 
5. Can minimize the occurrence of losses, by closing the insurance agreement, the risks that may be experienced can be eliminated and transferred to the insurance company;

6. Is an investment means to produce calmly and for the future because the risk has been transferred to the insurance company;

7. Is a contribution to economic development, in this case the premiums collected by insurance companies are investment funds in the country's economic development.

Facing the challenge of lack of public awareness of the importance of insurance can be done from the beginning of the development of the community itself, where insurance awareness cannot be separated from the level and quality of education of a society. Naturally, the basic attitude of each individual to risk is divided into 3 (three), namely not doing anything to risk (risk neutral), risk taking (risk taker), and risk avoidance (risk averter) [2]. Only through education and experience, understanding the risks and the dangers and the need for action to overcome them will be better.

\section{RESEARCH METHODS}

This research is a research on legal theory, especially legal protection theory from Philipus Hadjon. The legal material used is the Primary legal material, namely Law No. 40 of 2014 concerning Insurance, and Law No. 21 of 2011 concerning the Financial Services Authority (OJK); and secondary legal material consisting of books and newspapers and materials from the website. Collection of primary legal materials and secondary legal materials using documentary techniques by classifying existing legal materials and then presented in the form of narrative texts that are described and arranged systematically and logically. Legal material analysis that is collected and grouped is then reviewed with a philosophical approach and conceptual approach to obtain an overview of the problem of what is the meaning of policy guarantee to protect the insured person, then analyze qualitatively, that is to review and explain thoroughly and evaluate the legal material used.

\section{RESULT AND DISCUSSION}

Every human being in carrying out his activities faces various possibilities or risks [3]. Risk is basically an uncertainty (loss) or a complete loss is the possibility of a loss or cancellation of all or part of a profit that was originally expected, because of an event beyond human control, own error or other human actions [4]. The risks faced by humans are very broad, both regarding his life and wealth. Considering that risk is something that will always be there, every human being, both in his capacity as a person and as an entrepreneur, must be prepared to face these risks. This risk is primarily a pure risk (pure risk), where the pure risk is the risk seen in terms of losses alone [5].

In order to prepare for risk, it is necessary to manage risk. There are several ways that can be done to overcome the possibility of adverse risks such as avoiding risk, preventing the occurrence of risk and transferring the risk to other parties. This method of transferring risk to another party is called insurance. Efforts to prepare yourself in the face of risk by transferring to other parties in this case to the insurance company as the guarantor is the main reason for a person or company to close the insurance agreement. Someone who has the risk of holding an insurance agreement with the insurer, so that the insurer will provide compensation or a sum of money if the risk in question becomes a reality [5]. As against its achievements, the party that bears the risk will receive a sum of money in the form of premiums from the party that diverts the risk, thus it can be said that insurance is an institution related to risk, namely pure risk. The need to overcome risk results in an insurance company to divert or share risks [5].

The opinion of Richard M. Heins as quoted by [5] said that insurance functions as a tool to manage risk or risk management. This statement means that insurance is the best way to manage risks that might occur. As for the purpose of insurance there are two types, namely economic goals and social goals. Insurance with economic objectives means by diverting or dividing the risks that are economic, while insurance with social objectives is an insurance that has no purpose for a business but its main purpose is a social security to the community [5].

Insurance as a transfer and risk sharing institution is very useful for the community, company and for the development of the country of Indonesia, because insurance also provides coverage or protection for an event from a threat of harm that causes losses. The insured who closes the insurance agreement will feel protected, safe because it gets protection from the possibility of an event. Insurance is a term used to refer to actions, systems, and businesses associated with financial protection (or financial compensation) for the soul, goods or property, health and others who get reimbursement from unpredictable events previously it will happen, such as death, loss, damage or illness, which involves paying premiums regularly within a certain period of time instead of a policy that guarantees that protection.

Legal protection is defined as a form of government legal action or action that is given to legal subjects in accordance with their rights and obligations carried out based on positive law in Indonesia. Legal protection arises because of a legal relationship. Legal relations (rechtbetrekking) are interactions between legal subjects who have legal relevance or have legal consequences, namely the emergence of rights and obligations.

In the theory of legal protection by reference [1], said that there are two kinds of protection namely Preventive legal protection that aims to prevent the occurrence of disputes and repressive legal protection that aims to resolve disputes. There are two parties to this legal protection, namely the Government with its actions, and the People, who are subject to the government's actions. All means, including legislation that facilitates the submission of objections by the people before the government's decision to get a definitive form, is a preventive legal protection. The handling of legal protection by the Judiciary is repressive legal protection.

Other aspects of legal protection for the insured as part of the community, as well as users of financial products 
and services namely the establishment of the Financial Services Authority (OJK) with Law Number 21 of 2011 concerning the Financial Services Authority, especially Article 4, Article 28, Article 30, and Article 31 mandates OJK to provide protection to consumers and the public in the financial services sector. These articles clearly reveal the need for aspects of education and protection of the insured as a consumer which is an integral part of the duties of regulation and supervision that was not previously regulated in other financial services sector laws.

Article 4 of the OJK Law, aims to ensure that all activities in the financial services sector:

a. held regularly, fairly, transparently and accountably;

b. able to realize a sustainable and stable financial system; and

c. able to protect the interests of consumers and society.

Article 28 of the OJK Law, for the protection of consumers and the public, OJK has the authority to take measures to prevent consumer and community losses, which include:

a. provide information and education to the public on the characteristics of the financial services sector, services and products;

b. ask the Financial Services Institution to stop its activities if the activity has the potential to harm the community; and

c. other actions deemed necessary in accordance with the provisions of the legislation in the financial services sector.

\section{Article 30 of the OJK Law regulates:}

1. For the protection of consumers and the public, OJK has the authority to conduct legal defense, which includes:

a. order or carry out certain actions to the Financial Services Institution to resolve complaints of consumers who have been harmed by the Financial Services Institution in question;

b. file a lawsuit:

(i) to recover property owned by the party that has been harmed from the party causing the loss, either under the control of the party causing the loss or under the control of another party in bad faith;

(ii) to obtain compensation from parties that cause losses to the Consumer and / or Financial Services Institution as a result of violations of the laws and regulations in the financial services sector.

2. Replace losses as referred to in paragraph (1) letter b number 2 only to be used for payment of compensation to the injured party.

Article 31 of the OJK Law, further provisions regarding consumer and community protection are regulated by the OJK Regulation. The sound of the Articles mentioned above is only part of the Government through the Financial Services Authority (OJK) to accommodate consumer protection in general, so it is necessary to make a special rule that truly protects the insured in insurance. The rights and obligations of the parties must be further emphasized, so that the insurance company is no longer taking cover behind the standard contract that is made unilaterally.

In Article 53 of the Law of the Republic of Indonesia Number 40 of 2014 concerning Insurance, which states: (1) Insurance Companies and Sharia Insurance Companies must be participants in the policy guarantee program. (2) The implementation of the policy guarantee program as referred to in paragraph (1) is regulated by law. (3) When the policy guarantee program applies based on the law as referred to in paragraph (2), the provisions concerning the Guarantee Fund as referred to in Article 8 paragraph (2) letter d and Article 20 are declared not valid for Insurance Companies and Sharia Insurance Companies. (4) The law as referred to in paragraph (2) shall be established no later than 3 (three) years after this Law is promulgated.

From the provisions of Article 53 paragraph (1) of the Law of the Republic of Indonesia Number 40 of 2014 concerning Insurance, it is stated that Insurance Companies and Sharia Insurance Companies must be participants in the policy guarantee program. The regulation can be concluded that, of the entire insurance business must register as a member of the policy guarantee program.

Based on the aforementioned matters, it is reflected that the position of the policy holder / insured / participant in the agreement agreed upon is relatively weak so it needs the role of the supervisory authority in order to provide juridical protection. The involvement of the supervisory authority's role is based on several considerations, including:

a. Insurance Companies or Sharia Insurance Companies are institutions that collect and manage funds from the public; and

b. The promise of an Insurance Company to make a replacement to the policyholder / insured / participant in the future must be safeguarded by maintaining the sustainability of the Insurance Company in question.

\section{CONCLUSION}

The meaning of insurance policy for the insured is to provide legal protection and guarantee the rights of the insured against all possible events that might occur. The position of the insured is weak when compared to the position of the insurance company, resulting in many insured who suffer losses when they follow insurance programs offered by the insurance company. Especially when an insurance company goes bankrupt or experiences a state of revocation of its business license and is unable to pay an insurance claim, so that the loss is suffered by the insured, the company does not give refund to the insured. Then you can take the conclusion that legal protection for the insured party is still lacking, so that it results in a lack of public trust in insurance. Until now, insurance policies have not yet been realized, the arrangements designed for this policy guarantee program will be very good and awaited by the insured, so that their rights can be protected, and can increase public confidence in general for insurance.

\section{ACKNOWLEDGMENT}

I would like to say thank you to Prof. Dr. Suhariningsih, SH., SU. As a Promoter in the Law Science Program, Faculty of Law Universitas Brawijaya, Malang City. 


\section{REFERENCES}

[1] P. M. Hadjon, "Perlindungan hukum bagi rakyat di Indonesia,” Bina Ilmu, Surabaya, 1987.

[2] M. S. Sastrawidjaja, Hukum Asuransi: Perlindungan Tertanggung, Asuransi Deposito, Usaha Perasuransian. Alumni, 2003.

[3] A. Prawoto, "Hukum Asuransi dan Kesehatan Perusahaan Asuransi," Yogyakarta. BPFE UGM,
1995.

[4] I. Syamsoe and Soeprijanto, Dasar-dasar Pengetahuan Asuransi. Jakarta: Yayasan Pembina Keluarga UPN Veteran, 1989.

[5] M. Suparman, "Aspek-Aspek Hukum Asuransi dan Surat Berharga,” Bandung PT. ALUMNI, 2003. 